\title{
PENILAIAN BAHAN BERBAHAYA BERACUN PADA LABORATORIUM RADIOLOGI RSUD BANGIL KABUPATEN PASURUAN
}

\author{
ASSESSMENT HAZARD MATERIALS IN RADIOLOGICAL LABORATORY \\ RSUD BANGIL DISTRICT OF PASURUAN
}

\author{
Frans Salesman, Umi Farida \\ STIKES Citra Husada Mandiri Kupang \\ E-mail: franssalesman@gmail.com
}

\begin{abstract}
The consequence of activity in hospital is to produce toxic material waste (B3). So, description of B3 in the hospital was needed. The objective of this research was to identify the hazards in each stage in waste management of Liquid Hazardous and Toxic (B3) at Bangil Hospital, Pasuruan. Based on the place, this research was categorized as field research, because it used primary data by interviewing directly to the workforce and conducting risk assessment to the hazard source in the research location. This research was cross-sectional study. The results showed that there were 8 potential hazards, which consist of 3 hazards at the storage stage, 3 hazards at the collection stage, and each 1 hazard at the processing and disposal stage. The hazards proable experienced by laboratory personnel who also serve in the management of liquid waste and also those who operate the IPAL. While the management of B3 liquid waste radiology laboratory conducted by laboratory workers and IPS has 15 potential hazards, including 3 hazards at the storage stage, 6 hazards at the collection stage, 3 hazards at the transport stage and 3 hazards on the temporary storage. Based on the hazard identification at the stage of B3 waste management of Radiology Laboratory at Bangil General Hospital of Pasuruan, there were 15 potential hazards. While at the stage of waste management B3 Liquid Environmental Laboratory in RSUD Bangil Pasuruan, found 8 potential hazards.
\end{abstract}

Keywords: hazardous materials, hospital, radiological laboratory

\begin{abstract}
ABSTRAK
Konsekuensi dari proses kegiatan di rumah sakit antara lain menghasilkan limbah Bahan Berbahaya Beracun (B3). Sehingga, perlu dilakukan deskripsi terhadap B3 di rumah sakit. Tujuan riset adalah mengidentifikasi bahaya dalam setiap tahapan pengelolaan limbah Bahan Berbahaya dan Beracun (B3) cair laboratorium di RSUD Bangil, Kabupaten Pasuruan. Berdasarkan tempat penelitiannya maka penelitian ini dikategorikan sebagai penelitian lapangan, karena menggunakan data primer dengan wawancara secara langsung terhadap tenaga kerja dan melakukan penilaian risiko terhadap sumber bahaya di lokasi penelitian. Penelitian ini termasuk pada penelitian cross-sectional jika ditinjau dari pendekatan waktu. Berdasarkan hasil penelitian didapatkan 8 potensi bahaya, yang terdiri dari 3 bahaya pada tahap penyimpanan, 3 bahaya pada tahap pengumpulan, dan masing-masing 1 bahaya pada tahap pengolahan dan pembuangan. Bahaya tersebut mungkin dialami oleh petugas laboratorium yang juga bertugas dalam pengelolaan limbah cair dan juga pihak yang mengoperasikan IPAL. Pada pengelolaan limbah B3 cair laboratorium radiologi yang dilakukan oleh petugas laboratorium serta pihak IPS memiliki 15 potensi bahaya, diantaranya 3 bahaya pada tahap penyimpanan, 6 bahaya pada tahap pengumpulan, 3 bahaya pada tahap pengangkutan dan 3 bahaya pada penyimpanan sementara. Berdasarkan identifikasi bahaya pada tahap pengelolaan limbah B3 cair Laboratorium Radiologi di RSUD Bangil Kabupaten Pasuruan, ditemukan 15 potensi bahaya. Pada tahap pengelolaan limbah B3 cair, Laboratorium Lingkungan di RSUD Bangil Kabupaten Pasuruan, ditemukan 8 potensi bahaya.
\end{abstract}

Kata kunci: bahan berbahaya beracun, laboratorium radiologi, rumah sakit

\section{PENDAHULUAN}

Rumah sakit merupakan salah satu dari sarana kesehatan yang menyelenggarakan upaya kesehatan yaitu kegiatan untuk memelihara dan meningkatkan kesehatan serta bertujuan untuk mewujudkan derajat kesehatan yang optimal bagi masyarakat. Upaya kesehatan ini meliputi pemeliharaan, peningkatan kesehatan (promotif), pencegahan penyakit (preventif), penyembuhan penyakit (kuratif) dan pemulihan (rehabilitatif) 
yang dilaksanakan secara serasi dan terpadu serta berkesinambungan. Selain itu, peran rumah sakit sebagai sarana upaya perbaikan kesehatan serta sebagai lembaga pendidikan tenaga kesehatan dan penelitian, ternyata memiliki dampak positif dan negatif terhadap lingkungan sekitarnya. Kegiatan rumah sakit tersebut menghasilkan berbagai macam limbah yang berupa benda cair, padat dan gas. Hal ini mempunyai konsekuensi perlunya pengelolaan limbah rumah sakit sebagai bagian dari penyehatan lingkungan rumah sakit yang bertujuan untuk melindungi masyarakat dari bahaya pencemaran lingkungan yang bersumber dari limbah rumah sakit (Adisasmito, 2009).

Limbah tersebut dihasilkan dari kegiatan seluruh unit kerja di rumah sakit, tidak terkecuali unit laboratorium kesehatan. Menurut Keputusan Menteri Kesehatan Republik Indonesia No. 298/ Menkes/SK/III/2008 yang dimaksud dengan laboratorium kesehatan adalah sarana kesehatan yang melaksanakan pengukuran, penetapan dan pengujian terhadap bahan yang berasal dari manusia atau bahan bukan berasal dari manusia untuk penentuan jenis penyakit, kondisi kesehatan atau faktor yang dapat berpengaruh pada kesehatan perorangan dan masyarakat. Pada pelaksanaan kegiatan operasionalnya, laboratorium akan menghasilkan limbah yang sebagian besar adalah limbah cair yang berasal dari pencucian peralatan laboratorium dan bahan buangan hasil pemeriksaan seperti darah, urine, dan lain-lain. Limbah cair ini umumnya banyak mengandung berbagai senyawa kimia sebagai bahan pereaksi sewaktu pemeriksaan contoh darah dan bahan lain. Limbah cair laboratorium mengandung bahan antiseptik dan antibiotik sehingga bersifat toksik terhadap mikroorganisme, serta mengandung logam berat (Djohan dan Halim, 2014).

Berdasarkan Peraturan Pemerintah Nomor 101 Tahun 2014 tentang Pengelolaan Limbah Bahan Berbahaya dan Beracun (B3) Pasal 3 ayat (1), S bahwa setiap orang yang menghasilkan limbah B3 wajib melakukan pengelolaan limbah B3 yang dihasilkannya. Pengelolaan limbah tersebut berupa kegiatan yang meliputi pengurangan, penyimpanan, pengumpulan, pengangkutan, pemanfaatan, pengolahan dan/atau penimbunan.

RSUD Bangil Kabupaten Pasuruan merupakan salah satu rumah sakit telah melaksanakan pengelolaan limbah rumah sakit, khususnya terhadap limbah laboratorium. Lab yang terdapat di RSUD Bangil Pasuruan meliputi 5 lab, diantaranya yaitu laboratorium patologi klinik, patologi anatomi, radiologi, dan lingkungan. Lab yang menghasilkan limbah cair dengan karakteristik B3 yaitu lab lingkungan dan radiologi. Limbah yang dihasilkan dari lab lingkungan berupa hasil sisa uji sampel darah, urine, dahak dan lainnya. Sementara itu, lab radiologi menghasilkan limbah cair bekas cuci film rontgen yang mengandung logam berat berupa perak. sisa darah dan urine termasuk limbah cair yang bersifat infeksius karena mengandung bakteri virus dan lain-lain yang dapat menyebabkan terjadinya penularan penyakit.

Limbah lab radiologi yang dihasilkan dari bekas cucian film rontgen berupa cairan fixer dan developer. Limbah tersebut sangat berbahaya bagi kesehatan manusia bahkan dapat mengakibatkan pencemaran lingkungan.

\section{METODE}

Berdasarkan tempat penelitiannya maka penelitian ini dikategorikan sebagai penelitian lapangan, karena menggunakan data primer dengan wawancara secara langsung terhadap tenaga kerja dan melakukan penilaian risiko terhadap sumber bahaya di lokasi penelitian. Penelitian ini termasuk pada penelitian cross-sectional jika ditinjau dari pendekatan waktu. Apabila ditinjau dari teknik pengambilan datanya, penelitian ini merupakan penelitian observasional dengan sifat penelitian yaitu deskriptif karena penelitian ini hanya sebatas mendiskripsikan sejumlah variabel yang berkenaan dengan masalah yang sedang diteliti dan dilakukan pada periode tertentu saja. Sasaran penelitian ini adalah risiko bahaya dalam kegiatan pengelolaan Limbah Bahan Berbahaya dan Beracun (B3) cair laboratorium di Rumah Sakit Umum Daerah Bangil Kabupaten Pasuruan, dengan populasi penelitian yaitu petugas pengelolaan limbah B3 laboratorium. Penelitian ini dilaksanakan di RSUD Bangil Kabupaten Pasuruan dengan waktu penelitian dan pengambilan data dilakukan pada tanggal 4-18 April 2016. Variabel pada penelitian ini meliputi tahapan pengelolaan limbah B3, bahaya (hazard), identifikasi bahaya, risiko, penilaian risiko dan tingkat risiko. Data yang dikumpulkan pada penelitian ini adalah data primer dan data sekunder. Data primer meliputi observasi, wawancara, dan studi pustaka. Observasi dilakukan dengan mengamati secara langsung dilengkapi dengan lembar observasi risk assessment table atau berupa checklist, serta kamera untuk pengambilan gambar pelaksanaan 
kegiatan pengelolaan Limbah Bahan Berbahaya dan Beracun (B3) cair laboratorium yang diterapkan di RSUD Bangil Kota Pasuruan. Wawancara dilakukan secara langsung kepada responden, yaitu tenaga kerja yang bertugas dalam melaksanakan pengelolaan limbah B3 laboratorium yang kemungkinan berisiko terpapar bahaya. Wawancara dilakukan dengan menggunakan instrumen berupa panduan wawancara dengan metode Focuss Group Discussion (FGD). Studi pustaka dilakukan dengan mempelajari buku atau literatur kepustakaan, dan laporan penelitian yang sudah ada.

Data sekunder diperoleh dari data rumah sakit yang bersifat dokumenter dan tercatat di rumah sakit, seperti data mengenai gambaran umum rumah sakit, struktur organisasi rumah sakit dan sistem operasionalnya serta data mengenai sistem manajemen lingkungan dan dokumen hasil analisis risiko Limbah Bahan Berbahaya dan Beracun (B3), serta data rumah sakit yang berkaitan dengan penelitian, seperti Standard Operating Procedure (SOP) dan Work Instruction (WI) pengelolaan limbah B3 cair laboratorium.

Pengumpulan data penelitian dilakukan dengan cara observasi dan wawancara. Kegiatan observasi dilakukan menggunakan pedoman kuesioner yang diisi oleh tenaga kerja yang bertugas melakukan pengelolaan limbah Bahan Berbahaya dan Beracun (B3) cair laboratorium. Selain itu, kamera juga diperlukan untuk dokumentasi. Sedangkan wawancara dilakukan dengan cara tanya jawab secara langsung pada tenaga kerja dengan panduan daftar pertanyaan yang berhubungan dengan masalah penelitian.

Data yang diperoleh diolah dan dianalisis dengan metode deskriptif. Pengolahan data dilakukan dengan menghitung perkalian antara tingkat peluang (likelihood) dan tingkat keparahan (severity), kemudian hasilnya dikategorikan berdasarkan tingkat risiko rendah, risiko sedang dan risiko tinggi sesuai dengan tabel Risk Assessment Matrix. Penyajian hasil tingkat risiko dalam bentuk tabulasi frekuensi untuk melihat persentase tingkat risiko serta dinarasikan secara deskriptif.

\section{HASIL}

Berdasarkan tabel 1, terdapat 23 bahaya pada proses pengelolaan limbah B3 cair laboratorium lingkungan dan radiologi. Pada pengelolaan limbah B3 cair di laboratorium lingkungan didapatkan 8 potensi bahaya, yang terdiri dari
3 bahaya pada tahap penyimpanan, 3 bahaya pada tahap pengumpulan, dan masing-masing 1 bahaya pada tahap pengolahan dan pembuangan. Bahaya tersebut mungkin dialami oleh petugas laboratorium yang juga bertugas dalam pengelolaan limbah cair dan juga pihak yang mengoperasikan IPAL. Pada pengelolaan limbah B3 cair laboratorium radiologi yang dilakukan oleh petugas laboratorium serta pihak Instalasi Pemeliharaan Sarana (IPS) memiliki 15 potensi bahaya, diantaranya 3 bahaya pada tahap penyimpanan, 6 bahaya pada tahap pengumpulan, 3 bahaya pada tahap pengangkutan dan 3 bahaya pada penyimpanan sementara.

\section{PEMBAHASAN}

\section{Potensi Bahaya pada Tahap Pengelolaan Limbah B3 Cair Laboratorium Radiologi}

\section{Tahap Penyimpanan di Lokasi}

Pada tahap penyimpanan, kegiatan yang dilakukan yaitu memasukkan limbah cair hasil pencucian film rontgen ke dalam jerrycan dengan kapasitas 5-10 liter. Limbah tersebut akan mengalir dari mesin pencucian film rontgen ke dalam jerrycan, dan petugas pengelolaan limbah yang bertanggung jawab akan menuang cairan yang terkumpul ke dalam bak ukuran besar untuk selanjutnya dilakukan pengenceran.

Dalam tahap tersebut terdapat beberapa potensi bahaya diantaranya, bahaya pertama yaitu terkena cairan fixer dan developer. Proses pencucian film rontgen yang dilakukan di laboratorium radiologi menghasilkan limbah B3 cair yang mengandung perak. Limbah cair pencucian film rontgen mengandung senyawa perak nitrat dan perak bromida yang dapat menimbulkan keracunan seperti timbulnya warna biru keabu-abuan pada mata, sekat rongga hidung, tenggorokan dan kulit, iritasi pada kulit, borok dan gangguan pencernaan yang disebabkan oleh pemaparan yang berlebihan (over exposure) terhadap senyawa logam perak (Kuswati dkk, 2003). Pada tahap pengumpulan limbah cair tersebut, petugas laboratorium tidak menggunakan alat pelindung diri yang sesuai seperti sarung tangan, masker ataupun pakaian pelindung. Bahaya kedua yaitu cairan tumpah. Cairan limbah radiologi yaitu fixer dan developer termasuk limbah Bahan Berbahaya dan Beracun (B3). Ini berdasarkan penelitian Kuswati, dkk (2003), yang menyatakan 
Tabel 1. Identifikasi Bahaya pada Pengelolaan Limbah B3 Cair Laboratorium Radiologi Tahun 2016

\begin{tabular}{|c|c|c|c|c|}
\hline No & Tahapan pengelolaan & Langkah kerja & Bahaya & Pengendalian \\
\hline \multirow[t]{3}{*}{1} & \multirow[t]{3}{*}{ Penyimpanan di lokasi } & \multirow[t]{3}{*}{$\begin{array}{l}\text { Memasukkan limbah } \\
\text { cair radiologi (fixer } \\
\text { dan developer) dalam } \\
\text { bak }\end{array}$} & $\begin{array}{l}\text { Terkena cairan fixer dan } \\
\text { developer pekat yang } \\
\text { mengandung logam } \\
\text { berat perak nitrat dan } \\
\text { perak bromida }\end{array}$ & $\begin{array}{l}\text { - Penyediaan westafel untuk cuci } \\
\text { tangan (available) } \\
\text { - Disediakan sabun antiseptik } \\
\text { (no available) } \\
\text { - Penggunaan sarung tangan karet } \\
\quad \text { (no available) } \\
\text { - Penggunaan sepatu yang kedap } \\
\text { cairan (no available) }\end{array}$ \\
\hline & & & Cairan tumpah & $\begin{array}{l}\text { - Pembersihan dengan majun } \\
\text { kering (available) } \\
\text { - Pembersihan dengan air atau } \\
\text { pengenceran kandungan perak } \\
\text { (no available) }\end{array}$ \\
\hline & & & $\begin{array}{l}\text { Terpeleset akibat lantai } \\
\text { licin }\end{array}$ & $\begin{array}{l}\text { Penggunaan alas kaki dengan sol } \\
\text { karet (no available) }\end{array}$ \\
\hline \multirow[t]{7}{*}{2.} & \multirow[t]{7}{*}{ Pengumpulan } & \multirow{2}{*}{$\begin{array}{l}\text { Pengadukan larutan } \\
\text { yang telah diencerkan } \\
\text { dengan menggunakan } \\
\text { tangan pada proses } \\
\text { pengenceran limbah } \\
\text { cair fixer dan } \\
\text { developer dengan air }\end{array}$} & \multirow{2}{*}{$\begin{array}{l}\text { Terkena cairan fixer } \\
\text { dan developer pekat } \\
\text { mengandung logam } \\
\text { berat perak nitrat dan } \\
\text { perak bromida akibat } \\
\text { penambahan air yang } \\
\text { kurang hati-hati }\end{array}$} & $\begin{array}{l}\text { - Menggunakan sarung tangan } \\
\text { lateks saat menangani limbah } \\
\text { (no available) }\end{array}$ \\
\hline & & & & $\begin{array}{l}\text { Pengadukan dengan tuas dari kayu } \\
\text { karena sifat bahan kimianya yang } \\
\text { korosif (no available) }\end{array}$ \\
\hline & & \multirow[t]{4}{*}{$\begin{array}{l}\text { Memasukkan cairan } \\
\text { yang telah diencerkan } \\
\text { ke dalam jerrycan }\end{array}$} & $\begin{array}{l}\text { Terkena cairan pada } \\
\text { bagian tubuh (mata dan } \\
\text { membran mukosa) }\end{array}$ & $\begin{array}{l}\text { - Disediakan westafel untuk cuci } \\
\text { tangan (avalaible) } \\
\text { - Sebaiknya disediakan juga } \\
\text { sabun antiseptik (no available) }\end{array}$ \\
\hline & & & $\begin{array}{l}\text { Terpeleset akibat lantai } \\
\text { licin }\end{array}$ & $\begin{array}{l}\text { Menggunakan sepatu dengan sol } \\
\text { anti selip (no available) }\end{array}$ \\
\hline & & & $\begin{array}{l}\text { Terkena sengatan } \\
\text { listrik akibat kabel } \\
\text { yang berserakan dekat } \\
\text { pengisian cairan }\end{array}$ & $\begin{array}{l}\text { - Kabel masih terisolasi dengan } \\
\text { baik (available) } \\
\text { - Sebaiknya kabel tidak dibiarkan } \\
\text { menjalar di lantai atau dipasang } \\
\text { di dinding (no available) }\end{array}$ \\
\hline & & & $\begin{array}{l}\text { Cairan yang diencerkan } \\
\text { tumpah }\end{array}$ & $\begin{array}{l}\text { Dibersihkan dengan majun } \\
\text { (available) }\end{array}$ \\
\hline & & $\begin{array}{l}\text { Memindahkan } \\
\text { jerrycan yang } \\
\text { telah diisi ke lokasi } \\
\text { pengumpulan } \\
\text { sementara }\end{array}$ & $\begin{array}{l}\text { Terbentur mesin dan } \\
\text { barang-barang saat } \\
\text { memindahkan }\end{array}$ & Menata ulang peletakan mesin \\
\hline \multirow[t]{3}{*}{3.} & \multirow[t]{3}{*}{ Pengangkutan } & $\begin{array}{l}\text { Memindahkan limbah } \\
\text { cair dalam kemasan } \\
\text { ke luar ruangan secara } \\
\text { manual }\end{array}$ & $\begin{array}{l}\text { Bahaya ergonomi } \\
\text { (mengangkat beban } \\
\text { berlebih) }\end{array}$ & $\begin{array}{l}\text { Dengan menggunakan troli barang } \\
\text { (no avalaible) }\end{array}$ \\
\hline & & $\begin{array}{l}\text { Mengangkat limbah } \\
\text { cair dalam jerrycan ke } \\
\text { gerobak motor }\end{array}$ & $\begin{array}{l}\text { Bahaya ergonomi } \\
\text { (mengangkat beban } \\
\text { berlebih) }\end{array}$ & \\
\hline & & $\begin{array}{l}\text { Pengangkutan ke TPS } \\
\text { dengan gerobak motor }\end{array}$ & $\begin{array}{l}\text { Cairan tumpah saat } \\
\text { perjalanan }\end{array}$ & $\begin{array}{l}\text { Menutup rapat tutup jerrycan } \\
\text { (avalaible) }\end{array}$ \\
\hline
\end{tabular}




\begin{tabular}{|c|c|c|c|c|}
\hline No & Tahapan pengelolaan & Langkah kerja & Bahaya & $\begin{array}{l}\text { Pengendalian } \\
\end{array}$ \\
\hline \multirow[t]{3}{*}{4.} & Penyimpanan sementara & $\begin{array}{l}\text { Mengangkat limbah } \\
\text { cair dalam jerrycan } \\
\text { dan meletakkannya }\end{array}$ & $\begin{array}{l}\text { Terkena virus dan } \\
\text { bakteri dari limbah } \\
\text { medis }\end{array}$ & \\
\hline & & dalam ruang TPS & $\begin{array}{l}\text { Tertusuk limbah jarum } \\
\text { yang tercecer di sekitar } \\
\text { tempat penyimpanan } \\
\text { sementara }\end{array}$ & $\begin{array}{l}\text { Penggunaan safety shoes } \\
\text { (available) }\end{array}$ \\
\hline & & & $\begin{array}{l}\text { Bahaya ergonomi } \\
\text { (mengangkat beban } \\
\text { berlebih) }\end{array}$ & \\
\hline 5. & Pengolahan & $\begin{array}{l}\text { Dilakukan oleh pihak } \\
\text { ke-2 }\end{array}$ & & \\
\hline
\end{tabular}

Tabel 2. Risk Assessment Matrix

\begin{tabular}{lccccc}
\hline \multirow{2}{*}{ Likelihood } & \multicolumn{5}{c}{ Severity } \\
\cline { 2 - 6 } & (1) Insignificant & (2) Minor & (3) Moderate & (4) Major & (5) Catastrophic \\
\hline (1) Rare & 1 & 2 & 3 & 4 & 5 \\
(2) Unlikely & 2 & 4 & 6 & 8 & 10 \\
(3) Moderate & 3 & 6 & 9 & 12 & 15 \\
(4) Likely & 4 & 8 & 12 & 16 & 20 \\
(5) Almost & 5 & 10 & 15 & 20 & 25 \\
certain & & &
\end{tabular}

bahwa limbah cairan pencucian film foto rontgen mengandung unsur perak yang termasuk dalam logam berat yang dapat menyebabkan keracunan, iritasi kulit dan membran mukosa. Bahaya ketiga yaitu permukaan lantai di laboratorium radiologi yang licin. Lantai licin merupakan unsafe condition yang dapat menyebabkan terjadinya kecelakaan kerja yaitu petugas terpeleset saat melakukan penyimpanan limbah radiologi dalam bak atau jerrycan (Ramli, 2011).

\section{Tahap Pengumpulan}

Tahap pengumpulan terdiri dari tiga langkah pekerjaan, diantaranya pengenceran limbah cair fixer dan developer dengan menggunakan air, pengadukan cairan yang dilakukan oleh petugas laboratorium dengan menggunakan tangan, memasukkan limbah yang telah tercampur ke dalam jerrycan dan pemindahan jerrycan ke tempat penyimpanan sementara yang ada dalam ruangan.

Dari langkah pekerjaan pengenceran limbah cair fixer dan developer dengan menggunakan air terdapat potensi bahaya berupa terjadinya kontak langsung dengan cairan fixer dan developer. Kontak dengan cairan tersebut dapat menyebabkan iritasi kulit, dan (Kuswati dkk, 2003),

Pada langkah pekerjaan pengadukan cairan yang dilakukan oleh petugas laboratorium dengan menggunakan tangan, terdapat bahaya kontak antara kulit dengan cairan yang telah diencerkan. Proses pengadukan limbah cair fixer dan developer yang dicampur dengan air dilakukan dengan tangan tanpa menggunakan alat bantu pengaduk atau penggunaan sarung tangan maupun gloves. Berdasarkan penelitian yang dilakukan oleh Kuswati, dkk (2003) menyatakan bahwa dalam kandungan limbah cair fotografi atau pemrosesan film foto rontgen terdapat logam berat berupa perak nitrat dan perak bromida. Kontak langsung antara cairan fixer dan developer terhadap tangan memungkinkan tangan terkontaminasi logam berat yang terkandung dalam cairan. Paparan yang berkepanjangan (chronic exposure) terhadap senyawa perak dapat menyebabkan timbulnya warna 
biru keabu-abuan pada kulit yang dikenal dengan argyria atau argyrosis. Kontak kulit dengan perak nitrat sendiri dapat menyebabkan iritasi dan rasa seperti terbakar pada kulit dan membran mukosa.

Langkah selanjutnya adalah memasukkan cairan yang telah diencerkan ke dalam jerrycan. Pada kegiatan ini terdapat beberapa potensi bahaya diantaranya, bahaya pertama yaitu terkena cairan yang diencerkan pada daerah kulit dan mukosa akibat penanganan yang kurang tepat. Seperti yang telah dijelaskan di atas, bahaya cairan fixer dan developer yaitu. Bahaya kedua adalah permukaan lantai yang licin. Lantai yang licin dapat berpotensi menyebabkan kecelakaan kerja berupa petugas terpeleset apabila lantai terkena tumpahan atau ceceran limbah B3 cair (Ramli, 2011). Selain itu, kemungkinan terpeleset semakin besar karena petugas menggunakan sandal jepit saat pengisian dan pemindahan limbah B3 cair. Bahaya ketiga yaitu kemungkinan cairan tumpah. Bahaya tersebut berpotensi menyebabkan kontaminasi permukaan lantai oleh logam berat berupa perak. Bahaya keempat adalah terkena sengatan listrik akibat adanya kabel yang berserakan di lantai dekat tempat pengenceran dan pengisian limbah cair ke jerrycan (Ramli, 2011). Apabila terdapat tumpahan cairan mengenai kabel dan isolasi kabel terkelupas atau terbuka, maka kemungkinan petugas tersengat listrik semakin besar.

Langkah pekerjaan terakhir yaitu pemindahan jerrycan ke tempat penyimpanan sementara yang ada di dalam ruangan. Potensi bahaya yang mungkin terjadi yaitu petugas terbentur mesin yang terletak di kanan dan kiri tempat pengisian limbah cair ke dalam jerrycan. Saat memindahkan limbah tersebut ke area penyimpanan sementara, bahaya terbentur sangat mungkin terjadi karena ruangan yang sempit dan banyaknya barang yang disimpan di dalam ruangan. Potensi bahaya terbentur termasuk dalam kategori safety hazard (Ramli, 2011).

\section{Tahap Pengangkutan}

Tahap pengangkutan dilakukan oleh pihak IPS yang akan mengambil limbah cair radiologi, umumnya dilakukan setiap satu bulan sekali. Langkah pekerjaan dalam tahap pengangkutan yaitu memindahkan limbah cair radiologi dalam kemasan ke luar ruangan, pengangkatan limbah cair radiologi dalam kemasan ke atas kendaraan berupa gerobak motor, dan pengangkutan limbah ke TPS.

Pada langkah pekerjaan pemindahan limbah cair radiologi dalam kemasan ke luar ruangan, memiliki potensi bahaya ergonomi. Hal ini disebabkan pemindahan limbah tersebut dilakukan secara manual tanpa menggunakan troli. Dalam sekali pengangkutan, didapatkan 3-4 jerrycan yang harus dipindahkan, dan setiap jerrycan berkapasitas 20 liter. Bahaya ergonomi tersebut berisiko menyebabkan nyeri bahu, punggung dan terjadinya cidera otot saat pemindahan jerrycan ke transportasi gerobak motor untuk selanjutnya dikirim ke TPS (Nilamsari, 2016). Pengumpulan limbah B3 cair radiologi biasanya dilakukan 1 (satu) bulan sekali atau 2-3 kali dalam satu bulan setiap limbah cair telah terkumpul dalam jumlah banyak.

Dalam langkah pekerjaan pengangkatan limbah cair radiologi ke atas kendaraan berupa gerobak motor, terdapat potensi bahaya ergonomi. Pengangkatan beban yang berlebih dapat menyebabkan cidera otot, nyeri bahu dan tangan (Nilamsari, 2016).

Potensi bahaya selanjutnya adalah kemungkinan cairan tumpah saat perjalanan. Bahaya tersebut mungkin terjadi pada langkah kerja pengangkutan limbah radiologi ke TPS. Cairan tumpah saat perjalanan dapat terjadi karena pemasangan tutup jerrycan yang kurang rapat atau karena pengaruh goncangan dari kontur jalan yang tidak rata. Cairan yang tumpah pada gerobak motor tidak bermasalah, namun saat tumpah ke tanah maka dapat mencemari lingkungan tanah karena kandungan logam beratnya (Kuswati dkk, 2003).

\section{Tahap Penyimpanan Sementara}

Tahap penyimpanan sementara bertujuan untuk menyimpan limbah B3 cair yang telah dikemas beberapa waktu hingga pengambilan limbah oleh pihak ke-2 (kedua). Langkah pekerjaan pada tahap penyimpanan sementara yaitu petugas mengangkat limbah cair dalam jerrycan dari alat transportasi dan meletakkannya dalam ruang TPS.

Potensi bahaya yang terdapat pada tahap penyimpanan sementara yaitu bahaya ergonomi. Potensi bahaya ergonomi dapat terjadi karena pengangkatan beban berlebih. Jerrycan dengan kapasitas 20 liter diangkat secara manual oleh petugas IPS saat pemindahan dari gerobak motor ke ruangan TPS. Risiko yang dapat terjadi yaitu timbul rasa nyeri pada bahu dan punggung (Nilamsari, 2016). Bahaya kedua adalah petugas tertusuk jarum suntik. Jarum suntik yang telah dikumpulkan oleh petugas limbah medis dan dikemas dalam plastik, sebagian masih diletakkan di depan ruang TPS dan sebagian berserakan. Hal ini memungkinkan 
terjadinya kecelakaan kerja berupa tertusuk jarum suntik saat penyimpanan sementara limbah cair radiologi ke TPS. Risiko yang dapat terjadi berupa infeksi dan penularan penyakit dari media jarum suntik (Djohan, 2013). Dalam tahap penyimpanan sementara, petugas menggunakan safety shoes untuk perlindungan. Bahaya ketiga yaitu terkena virus dan bakteri. TPS merupakan tempat penyimpanan sementara limbah medis yang dihasilkan oleh kegiatan operasional rumah sakit. Menurut Husodo (2011) limbah medis tergolong infeksius karena mengandung virus dan bakteri. Saat proses penyimpanan sementara, kemungkinan kontak dengan limbah medis yang ditimbun di TPS juga besar. Sehingga potensi bahaya kontaminasi virus dan bakteri juga sangat mungkin terjadi.

\section{Potensi Bahaya pada Tahap Pengelolaan Limbah B3 Cair Laoratorium Lingkungan}

\section{Tahap Penyimpanan}

Tahap penyimpanan, terdiri dari 2 (dua) langkah pekerjaan diantaranya pengambilan cairan darah dari mesin analisis dan pembersihan sisa reagen untuk kegiatan analisis. Langkah pekerjaan berupa pengambilan cairan darah atau urine dari mesin analisis dilakukan oleh petugas laboratorium lingkungan tanpa menggunakan sarung tangan lateks. Hal ini berisiko menyebabkan penularan penyakit melalui kontak antara tangan petugas dengan darah atau urine yang mungkin mengandung virus dan bakteri yang berperan sebagai agen infeksius (Husodo, 2011). Bahaya selanjutnya yaitu cairan darah atau urine tumpah saat penanganan. Cairan darah dan urine pada tabung reaksi yang diletakkan dalam wadah mungkin saja tumpah dan mengotori lantai. Hal ini berpotensi kontaminasi virus atau bakteri yang terdapat dalam cairan darah dan urine pada permukaan lantai. Potensi bahaya tersebut harus diperhatikan, mengingat ruangan uji harus tetap steril. Selain itu, potensi bahaya tertular penyakit dapat terjadi terhadap petugas laboratorium yang membersihkan cairan yang tumpah (Husodo, 2011). Langkah kerja berikutnya yaitu pembersihan reagen sisa uji analisis. Potensi bahaya yang terdapat pada tahap pengumpulan yaitu terkena bahan reagen sisa pengujian darah atau urine pasien di dalam laboratorium. Risiko yang dapat terjadi akibat kontak dengan zat kimia sisa yang dapat menyebabkan iritasi ringan atau alergi (Suharto, 2011).

\section{Tahap Pengumpulan}

Tahap pengumpulan dilakukan dengan cara mengumpulkan cairan sampel darah dan urine yang telah diuji ke westafel pembuangan. Bahaya pertama yang ada pada tahap pengumpulan adalah terkena darah atau urine yang mengandung virus dan bakteri. Bahaya tersebut termasuk bahaya biologi yang berisiko menyebabkan penularan penyakit (Husodo, 2011). Hal ini disebabkan oleh kemungkinan kontak antara kulit petugas laboratorium dengan cairan darah yang dibuang ke westafel. Hal tersebut mungkin terjadi, mengingat petugas tidak menggunakan sarung tangan saat melakukan pengumpulan cairan darah ke westafel. Bahaya kedua yaitu sampel darah dan urine tumpah saat pengumpulan. Cairan darah dan urine pada tabung reaksi yang diletakkan dalam wadah mungkin saja tumpah dan mengotori lantai. Hal ini berpotensi kontaminasi virus atau bakteri yang terdapat dalam cairan sampel darah dan urine pada permukaan lantai. Selain itu, potensi bahaya tertular penyakit dapat terjadi terhadap Cleaning Service (CS) yang membersihkan cairan yang tumpah (Husodo, 2011). Bahaya ketiga adalah permukaan lantai yang licin. Lantai ruangan laboratorium lingkungan yang terbuat dari keramik menyebabkan permukaan lantai licin untuk dipijak sehingga berisiko menyebabkan petugas dapat terpeleset yang termasuk dalam kategori safety hazard (Ramli, 2011). Tingkat risiko juga meningkat karena petugas menggunakan sepatu dengan sol yang tidak terbuat dari karet atau sol anti selip.

\section{Tahap Pengolahan}

Proses pengolahan limbah B3 cair laboratorium dijadikan satu dengan limbah cair rumah sakit lainnya dalam IPAL. Sebelum masuk ke saluran IPAL, limbah B3 cair laboratorium akan diolah terlebih dulu di Unit Rotating Biological Contactor (RBC). Proses tersebut berlangsung secara otomatis sehingga hampir tidak ada potensi bahaya terhadap pekerja. Namun terdapat penambahan bahan kimia pada kegiatan operasional IPAL yang kemungkinan dapat menyebabkan iritasi ringan (Suharto, 2011).

\section{Tahap Pembuangan}

Pembuangan air limbah yang telah dilakukan pengujian kualitas mutu telah memenuhi beberapa standar yang ditentukan. Aktivitas pembuangan 
air limbah dilakukan secara otomatis yang tidak melibatkan tenaga kerja dalam pelaksanaannya, sehingga hampir tidak ada potensi bahaya terhadap tenaga kerja. Namun dalam pelaksanaannya, setelah melalui uji kualitas mutu, kadar phosphat masih tinggi dan melampaui batas NAB. Sehingga mungkin menyebabkan pencemaran lingkungan air.

\section{SIMPULAN}

Berdasarkan identifikasi bahaya pada tahap pengelolaan limbah B3 cair Laboratorium Radiologi di RSUD Bangil Kabupaten Pasuruan, ditemukan 15 potensi bahaya. Sedangkan pada tahap pengelolaan limbah B3 cair Laboratorium Lingkungan di RSUD Bangil Kabupaten Pasuruan, ditemukan 8 potensi bahaya.

\section{DAFTAR PUSTAKA}

Anonim. 2011. Pedoman Praktis Manajemen Risiko dalam Perspektif K3. Jakarta: Dian Rakyat.

Adisasmito, W., 2009. Sistem Manajemen Lingkungan Rumah Sakit. Jakarta: Rajawali Pers.

Astra, W., 2008. Presentation Proposal for Asia Pasific HSEQ Manager's Meeting. Singapura.

Australian Standard and New Zealand Standard. 4360.2004.

Djohan \& Halim., 2013. Pengelolaan Limbah Rumah Sakit. Jakarta: Salemba Medika.

Fuji., 1973. Pengaruh Logam Berat Terhadap Lingkungan. Jakarta: Perwata Oceana.

Husodo, Adi Heru., 2008. Dampak Kesehatan Masyarakat Akibat Limbah Layanan Kesehatan (Termasuk Rumah Sakit dan Puskesmas). Yogyakarta: Universitas Gadjah Mada.

Kementerian Kesehatan Nomor 1204 Tahun 2004 tentang Persyaratan Kesehatan Lingkungan Rumah Sakit. Jakarta: Kementerian Kesehatan.

Keputusan Kepala Badan Pengendalian Dampak Lingkungan Nomor KEP-01/BAPEDAL/09/1995 tentang Tata Cara Persyaratan Teknis Penyimpanan dan Pengumpulan Limbah Bahan Berbahaya dan Beracun. Jakarta: Bapedal.

Keputusan Menteri Kesehatan Nomor 298/Menkes/ SK/III/2008 tentang Pedoman Akreditasi Laboratorium Kesehatan. Jakarta: Kementerian Kesehatan.

Kolluru, Rao \& Bartell, Steven., 2000. Risk Assessment and Management Toronto: Hanbook. McGraw-Hill.
Kuswati, H., Darmo H., \& Indrajati K., 2003. Perolehan Kembali Logam Perak Dari Limbah Cair Pencucian Film Studio Dibanding Film X-Ray dengan Menggunakan Metode SN Flake.

Nilamsari, N., 2016. Ergonomi dan Faal Kerja. Surabaya: Universitas Airlangga.

Occupational Health and Safety Assessment Series 18001. 2007

Peraturan Pemerintah Nomor 74 Tahun 2001 tentang Pengelolaan Bahan Berbahaya dan Beracun (B3). Jakarta: Kementerian Lingkungan Hidup.

Peraturan Pemerintah Nomor 82 Tahun 2001 tentang Pengelolaan Kualitas Air \& Pengendalian Pencemaran Air. Jakarta: Kementerian Lingkungan Hidup.

Peraturan Pemerintah Nomor 101 Tahun 2014 tentang Pengelolaan Limbah Bahan Berbahaya dan Beracun (B3). Jakarta: Kementerian Lingkungan Hidup.

Ramli, S., 2010. Pedoman Manajemen Risiko dalam Perspektif K3 OHS Risk Management. Jakarta: Dian Rakyat.

Said, AA., 2012. Analisis Pelaksanaan Teknik Job Safety Analysis (JSA) dalam Identifikasi Bahaya di Tempat Kerja pada Terminal Y PT X di Kabupaten Kutai Kertanegara Kalimantan Timur. Skripsi. Jakarta: Universitas Islam Negeri Syarif Hidayatullah Jakarta.

Siswanto., 2009. Toksikologi Amonia. Surabaya: Balai Hiperkes.

Soemirat, J., 1994. Kesehatan Lingkungan. Yogyakarta: Gadjah Mada University Press.

Suharto, I., 2011. Limbah Kimia dalam Pencemaran Udara dan Air. Yogyakarta: CV Andi Offset.

Tarwaka., 2008. Keselamatan dan Kesehatan Kerja. Surakarta: Harapan Press.

Tualeka, AR., 2013. Pengelolaan Aman Limbah Industri. Surabaya: Graha Ilmu Media. 2015. Risk Assessment, Risk Management \& Risk Communication di Lingkungan Kerja. Surabaya: Bumi Lestari.

Undang-Undang Nomor 23 Tahun 1992 tentang Kesehatan. Jakarta: Kementerian Kesehatan.

Undang-Undang Nomor 32 Tahun 2009 tentang Perlindungan dan Pengelolaan Lingkungan Hidup (PPLH). Jakarta: Kementerian Lingkungan Hidup.

Zulkifli,A., 2014. Pengelolaan Limbah Berkelanjutan. Yogyakarta: Graha Ilmu. 